\title{
DE ÁFRICA, DE ÁFRICAS E OUTROS SILENCIAMENTOS: DA TRADIÇÃO ORAL À MATERIALIDADE FICCIONAL DE PAULINA CHIZIANE
}

\author{
Rafael Hofmeister de Aguiar (UFRGS) ${ }^{1}$ \\ Daniel Conte (FEEVALE) ${ }^{2}$ \\ Ana Lúcia Tettamanzy (UFRGS) ${ }^{3}$
}

\section{RESUMO}

Este trabalho aborda uma concepção relacional entre colonizador e colonizado e alguns silenciamentos históricos impostos à África, a partir do romance Sétimo juramento, de Paulina Chiziane (2000). Primeiramente, volta-se à construção do discurso colonialista nas reflexões Shoahat e Stam (2006), remetendo aos estereótipos culturais acerca de África e da sua transformação em preconceitos sobre o continente. Depois, objetiva-se ver como a ficção de Chiziane rompe com os silenciamentos de África, trazendo à tona uma tradição oral moçambicana que sofreu processo de apagamento ao longo da história.

Palavras-chave: Tradição. Oralidade. Colonizador. Colonizado. Chiziane.

\section{DE ÁFRICA, DE ÁFRICAS Y OTROS SILENCIAMIENTOS: DE LA TRADICIÓN ORAL A LA MATERIALIDAD FICCIONAL DE PAULINA CHIZIANE}

\section{RESUMEN}

Este trabajo aborda una concepción relaccional entre colonizador y colonizado y algunos silenciamentos históricos impuestos a África, a partir de la novela Sétimo juramento, de Paulina Chiziane (2000). Primeramente, se vuelta a la construcción del discurso colonialista baseándose en las reflexiones de Shoahat y Stam (2006) que remiten a los estereotipos culturales acerca de África y de su transformación en 
prejuicios sobre el continente. Después, se objetiva ver cómo la ficción de Chiziane rumpe con los silenciamentos de África, elevando una tradición oral mozambicana que sufrió un proceso de borramento a lo largo de la Historia.

Palabras clave: Tradición. Oralidad. Colonizador. Colonizado. Chiziane.

\section{PARA INÍCIO DE CONVERSA OU UMA POSSÍVEL INTRODUÇÃO}

O Discurso sobre o colonialismo (1953), de Aimé Césaire, nas relações e produções sobre a História afro-asiática, apresenta-se como um documento duro e revelador das relações semântico-sociais entre colonizador e colonizado. É certo que as independências das colônias africanas já haviam sido conquistadas, mas o deparar-se com o vazio semeado e a avassaladora violência cultural faz Césaire escrever um texto denunciador, explicitador daquilo que foi a prática colonialista. Nele, o autor mostra num estilo abrasivo o motivo porque defende a máxima de que a "colonização desumaniza". A ideia principal defendida pelo escritor é a da inflexibilidade da Europa e de sua incompetência administrativa que traz à tona um conceito de colonização cruel e desenfreado, legitimado pelo poder da Igreja, que o justifica em nome de Deus, avassalando o Outro (o colonizado) e impondo um silêncio animalizador.

Diz Césaire (1953) que não há a possibilidade de se conferir à Europa o adjetivo grau de "colonizadora", uma vez que não consegue solucionar seus problemas domésticos e se mostra uma civilização incapaz de resolver-se. O argumento é perfeitamente legitimado pelos exemplos históricos que traz e pela percepção sensível da violência praticada contra a África. Em uma das passagens do livro, observa, sustentando seu discurso e perguntando a si mesmo, num evidente chamamento a seu narratário:

Onde quero chegar? A esta ideia; que ninguém coloniza inocentemente, nem ninguém coloniza impunemente, que uma nação que coloniza que uma nação que justifica a colonização - portanto, a força - é já uma civilização doente, uma civilização moralmente ferida que, irresistivelmente, de conseqüência em conseqüência, de negação em negação, chama o seu Hitler, isto é, seu castigo. (CÉSAIRE, 1978, p. 21). 
Apresenta-se esterilizado o espaço de diálogo dentro das relações estabelecidas pelos colonizadores, pois o valor atribuído ao Outro está dado já conceitualmente quando pensamos em colonizar, até porque entre colonizador e colonizado "só há lugar para o trabalho forçado, a intimidação, a pressão, a polícia, o imposto, o roubo, a violação, as culturas obrigatórias, o desprezo, a arrogância, a suficiência, a grosseria, as elites descerebradas, as massas aviltadas" (CÉSAIRE, 1953, p. 25). Isso tudo que gera um sistema que vai esvaziar sociedades, menosprezar culturas, corroer instituições seculares e relegar ao silenciamento conceitual produções artísticas, é que vai predominar dentro da ordem colonial.

A Europa, em nome de Deus, priva sociedades e viola culturas que se constituíam organizadas há centenas de anos. Atribui um valor positivo onde há insensibilidade etnográfica, impõe sua maior invenção de todos os tempos: a ideia do "negro bárbaro".

E é sobre esta caliça existencial implementada e organizada pela burguesia ${ }^{4}$, porque é bom dizer que essa burguesia está "condenada quer queira, quer não a ser responsável por toda a barbárie da História, as torturas da Idade Média e a Inquisição, a razão de Estado e o belicismo, o racismo e o escravagismo" (CÉSAIRE, 1953, p. 57), é sobre esses restos que se vai construir na África a resistência. Sobre o medo se desenhará a luta, e sobre o alargamento armado nascerá a república. Nesse contexto, há a emergência de uma funcionalidade colonialista antes não tida. Embora Portugal se revelasse incompetente em sua prática colonial, como se poderá ver mais adiante, logrou perfeitamente a desorientação necessária para o esfacelamento das referências nacionais, ou melhor, tribais dentro do território moçambicano. $O$ fomento dado às guerras tribais, recuperando o secular conceito "dividir para dominar", fez com que se acelerasse o processo de deterioração referencial e se estimulasse a fragmentação tribal com o choque de culturas locais, o que exauria, em parte, do africano, o sentimento de colonizado, uma vez que se the atrelava como unidade referencial colonizadora.

A partir desta concepção relacional entre colonizador e colonizado, de Césaire, abordamos alguns silenciamentos históricos impostos à África, através da abordagem do romance Sétimo juramento, de Paulina Chiziane (2000). Primeiramente, volta-se à construção do discurso colonialista considerando as reflexões Shoahat e Stam (2006), remetendo aos estereótipos culturais acerca de África e da sua transformação em preconceitos acerca do continente. Depois, 
objetiva-se ver como a ficção de Chiziane rompe com os silenciamentos de África, trazendo à tona uma tradição moçambicana que sofreu um processo de apagamento ao longo da história.

\section{PARA PENSAR O DISCURSO COLONIALISTA: A ÁFRICA ENTRE SILENCIAMENTOS, ESTEREÓTIPOS E PRECONCEITOS}

Shoahat e Stam (2006, p. 89) iniciam o seu estudo Crítica da imagem eurocêntrica: multiculturalismo e representação analisando o enunciado de panfletos de turismo acerca da Grécia. Em todos eles, há um discurso de que a Grécia seja o berço da civilização, negando, dessa forma, quaisquer papeis representacionais a outras civilizações antigas. Nesse sentido, é erigido “[...] um imaginário paneuropeu, usando tudo para nos remeter a uma narrativa mestra de origem semidivina" (SHOHAT; STAM, 2006, p.89). Como mostram os autores, não se pode render a essa visão de que a história se inicia com os gregos; outros povos contribuíram para o desenvolvimento da sociedade humana, perpetuando seu código imaginário pela oralidade.

Mesmo durante o período clássico, o palco da história se espalhava pelo globo: na China, no vale Hindu, na Mesopotâmia, na África, no que chamamos hoje de Américas, e, na verdade, onde quer que existissem seres humanos. (SHOHAT; STAM, 2006, p. 91).

Aliás, a exclusão de alguns povos, como os africanos, da história da humanidade funciona como um mecanismo silenciante dessas civilizações, um intento de apagar sua memória. Esses silenciamentos constroem-se ideologicamente, envolvendo o prestígio cultural de uma ou outra civilização, como ocorre na contraposição Grécia versus Egito.

\footnotetext{
Se a formulação de uma versão afrocêntrica alternativa da história reproduz, em um certo nível, em outro o inverte: ao levar em conta a inverte: ao levar em conta uma longa história de preconceito com os africanos, essas versões afirmam um passado e uma genealogia produtiva em que a ênfase não está tanto nas "origens" da civilização, mas no "início" de uma consciência política. A visão afrocêntrica mostra que debates sobre a Grécia e o Egito são batalhas que envolvem boa dose de prestígio cultural. Questões sobre as origens se tornam, assim, inseparáveis da genealogia política das identidades diaspóricas (SHOHAT; STAM, 2006, p. 92).
} 
No embate de prestígios culturais, houve um apagamento de toda influência africana ou asiática sobre a Grécia - civilização escolhida como modelo pelo discurso eurocêntrico. Nas palavras de Shohat e Stam (2006, p. 92-93), esse processo se deu através do "modelo ariano", que se desenvolveu à sombra da escravidão e do colonialismo, e realizou acrobacias incríveis para "purificar" a Grécia clássica de todas as "contaminações" africanas e asiáticas.

Há, a partir daí, uma deliberada campanha de degradação cultural da África pela visão eurocêntrica. Tal degradação é construída através do estabelecimento de categorias axiológicas arbitrárias e de matiz europeia.

O discurso eurocêntrico degradou sistematicamente a África ao considerá-la
deficiente de acordo com critérios e hierarquias arbitrárias criadas pelos
europeus (a valorização da arquitetura monumental e da cultura literária, da
melodia em detrimento da percussão, do tijolo em detrimento da palha, do
vestuário em detrimento da decoração do corpo). Entretanto, mesmo com
base em tais critérios duvidosos, a África pré-colonial possuía uma cultura
rica e diversificada - era palco de conquistas materiais significativas (como
demonstram as ruínas no Zimbábue), de amplo intercâmbio comercial, de
crenças religiosas e sistemas sociais complexos, bem como diversas formas
de escrita (pictogramas e ideogramas) (SHOHAT; STAM, 2006, p. 93).

Como se pode perceber, ocorre a valorização de critérios e hierarquias europeias com o intuito de desvalorizar a África. As categorias elencadas por Shohat e Stam (2006) podem ser sintetizadas no quadro abaixo. Nele, acrescentou-se a dupla escrita $x$ oralidade, uma vez que se compreende que o discurso eurocêntrico promoveu uma valorização da escrita com o objetivo de desprestigiar a oralidade. Essa oralidade sofre um processo de desqualificação, pois ela é a forma pela qual os saberes são enunciados e transmitidos nas sociedades tradicionais africanas.

Quadro 1 - Categorias axiológicas arbitrárias do discurso eurocêntrico

\begin{tabular}{|l|l|}
\hline Categorias prestigiadas & Categorias desprestigiadas \\
\hline Arquitetura monumental e cultura literária & \\
\hline Melodia & Percussão \\
\hline Tijolo & Palha \\
\hline Vestuário & Decoração do corpo \\
\hline Escrita & Oralidade \\
\hline
\end{tabular}

Quadro elaborado pelos autores. 
O discurso eurocêntrico, ao calcar tais categorias axiológicas, constrói a visão de uma África atrasada, através do esquecimento de dados históricos, tal como fato de que no início do comércio atlântico, a Europa pouco ou nada tinha a oferecer para a África. Da mesma forma, o eurocentrismo livrou-se de todas as influências africanas que sofreu. Há uma construção de superioridade por meio de apagamentos e silenciamentos. Nos primeiros anos de comércio atlântico,

[...] a Europa tinha pouca coisa para vender na África que os africanos já não possuíssem. A "inferioridade" da África, portanto, foi uma invenção ideológica que exigiu "o apagamento da consciência histórica ocidental do significado da Núbia para a formação do Egito, do Egito para o desenvolvimento da civilização grega, da África para a Roma imperial e, mais marcadamente, da influência do Islã sobre a história econômica, política, e intelectual da Europa". (SHOHAT; STAM, 2006, p. 93-94).

Esse é um breve panorama do discurso colonialista e eurocêntrico. Faz-se necessário pensar como ele construiu estereótipos acerca de África e como eles são matizes para uma perspectiva preconceituosa sobre o continente.

\section{PARA EVIDENCIAR ALGUNS ESTEREÓTIPOS: ÁFRICA EM IMAGENS}

No percurso que Shohat e Stam fazem do discurso eurocêntrico, tanto sobre a África quanto sobre a América, os autores partem de produções cinematográficas. Nesse trabalho, optou-se por realizar uma breve reflexão a partir de algumas imagens e vídeos contidos, acerca de África, na Web.

A primeira imagem que se traz é a contida em um desenho do Walt Dysney. Nela há um estereótipo de uma África selvagem, representada na figura do canibal.

\section{Imagem 1 - Mickey no caldeirão}

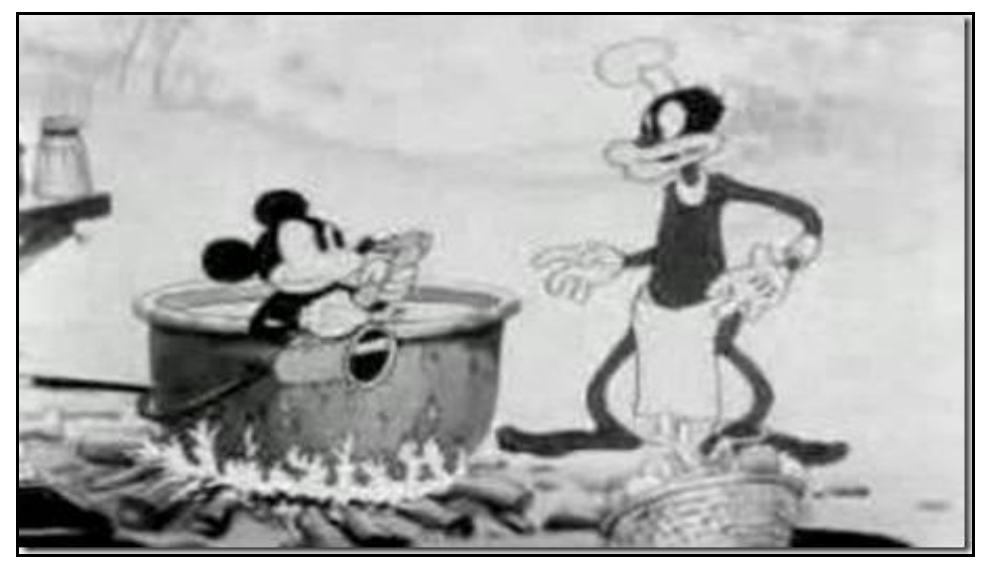


A representação imagética acima provém de um desenho animado ${ }^{5}$. Esse traz a imagem de uma África primitiva, em que impera a antropofagia. Ademais, pautado na ideologia do colonialismo, o audiovisual apresenta a tribo africana saqueando a embarcação em que viajavam as personagens Mickey e Pluto, quando, em verdade, quem saqueou África foram as potências ocidentais em sua prática colonial, causando uma inversão dos signos históricos. Há o intento de uma inversão da realidade histórica a fim de anular a imagem do Outro: além de [in]civilizado, o africano é apresentado como usurpador da propriedade daquele que constitui a civilização.

Outro desenho encontrado no Youtube com o personagem de Walt Disney também retrata a África como selvagem. Trata-se de Jungle rhythm. ${ }^{6}$ Nele, Mickey, já de início, aparece dançando sobre um elefante. A partir de então, surge a imagem de animais africanos, e alguns não tão africanos assim, como o urso, o que demonstra o desconhecimento a respeito da própria região que se quer retratar.

A visão da África como selvagem também aparece quando se quer fomentar o turismo no continente. Na imagem 2, uma manada de elefantes é apresentada com a legenda "Descubra o mundo que há na África". A associação da palavra à imagem de que África é, ainda, um continente selvagem em que tudo que se pode descobrir é sua fauna, desconsiderando, dessa forma, o elemento humano, pois ele, na visão do estereótipo, é incivilizado. É dessa prática que se ritualiza a valorização da palavra e a descartabilidade da cultura oral, já que a imagem constituída, por si, não é dizente. A legenda apresenta-se como elemento da racionalidade colonial e traz consigo o desvelamento de um mundo que, até então, estava coberto. 


\section{Imagem 2 - Descubra o mundo que há na África}

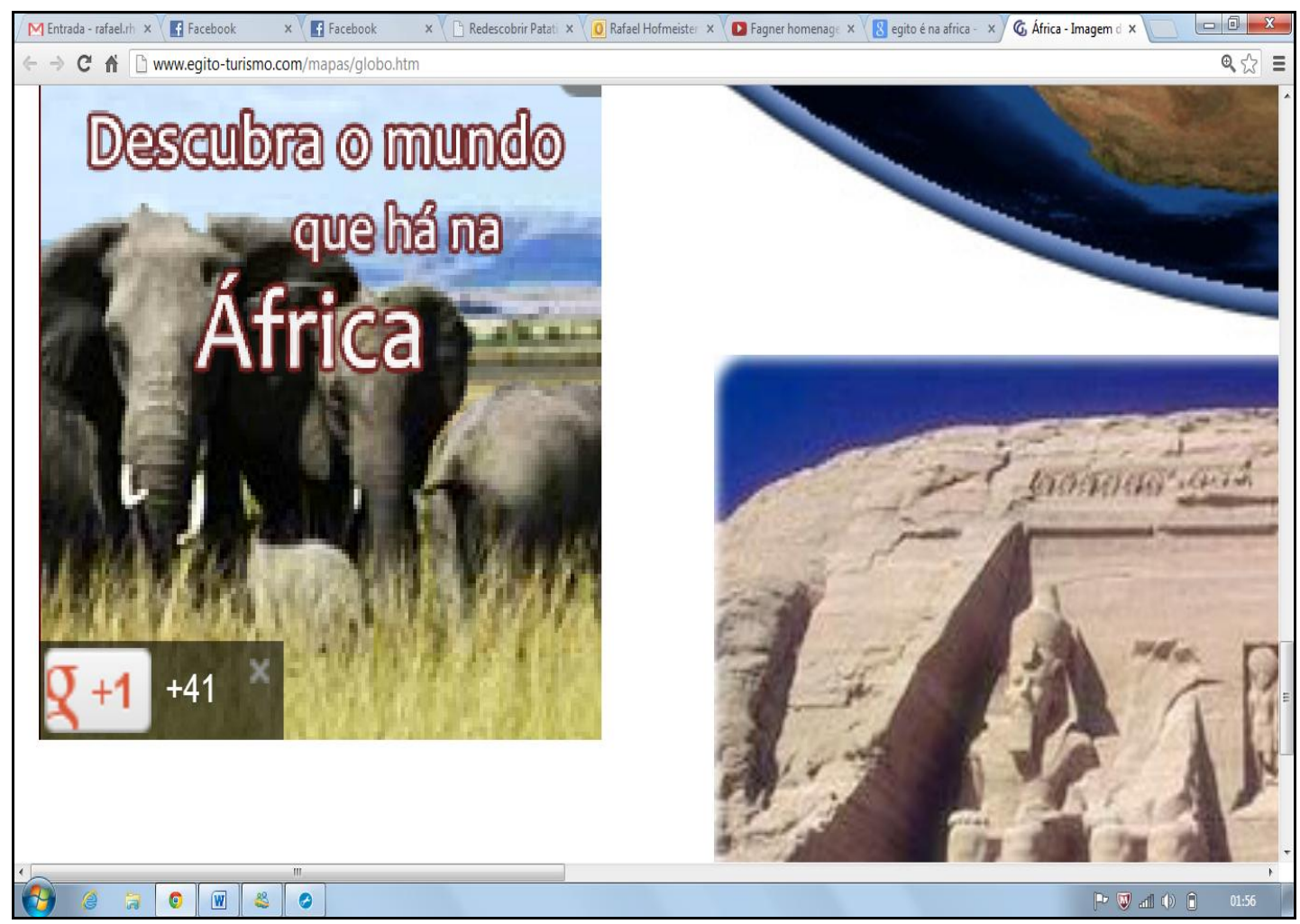

Ainda, tal pretensão de apresentar a África como selvagem coaduna com a compreensão de estereótipo apresentada por Burke (2004, p. 157).

Talvez seja por essa razão que os estereótipos muitas vezes tomam a forma de inversão da auto-imagem do espectador. Os estereótipos mais grosseiros estão baseados na simples pressuposição de que "nós" somos humanos ou civilizados, ao passo que "eles" [os outros] são pouco diferentes de animais como cães e porcos, aos quais eles são frequentemente comparados, [...]. Dessa forma, os outros são transformados no "Outro". Eles são transformados em exóticos e distanciados do eu e podem mesmo ser transformados em monstros.

A construção do estereótipo, como se percebe na exposição do historiador, passa pela consideração do Outro como o não-civilizado. Mais um exemplo dessa construção imagética da África são As aventuras de Tintim na África ${ }^{7}$. Há, no cartum de Hergé (2013), a visão de que o africano é atrasado e que o branco europeu tem um papel civilizador. Povoam o texto expressões como: "O branco é mais justo" e "Se você não estudar bastante, jamais será como Tintim". O conhecimento das narrativas escutadas não é válido, não existe um movimento de apreço às demandas de mundo perpetuadas oralmente, o que se apresenta valorizado é o conhecimento trazido pela escola - aparelho ideológico-repressor do Estado 
colonial. Apresenta-se, aí, a ideologia do homem europeu como justo e como exemplo a ser seguido pelo africano, que é tido como selvagem, vinculado em tempo à sua oralidade imagética.

\section{4 ÁFRICA: DOS ESTEREÓTIPOS AO PRECONCEITO}

Conforme se evidencia na exposição de Burke (2004, p. 157), o estereótipo leva ao preconceito, uma vez que os outros "podem mesmo ser transformados em monstros". Tal percepção é constatável em algumas representações que se têm da África. Dois exemplos de cunho religioso advindos do sítio Yahoo! Respostas ajudam a atestar tal interpretação.

No primeiro, há a pergunta sobre qual a sede de Satanás. A África está entre as possibilidades enunciadas pelo sujeito que elabora a questão, (Imagem 3 ).

\section{Imagem 3 - Sede de Satanás na África?}

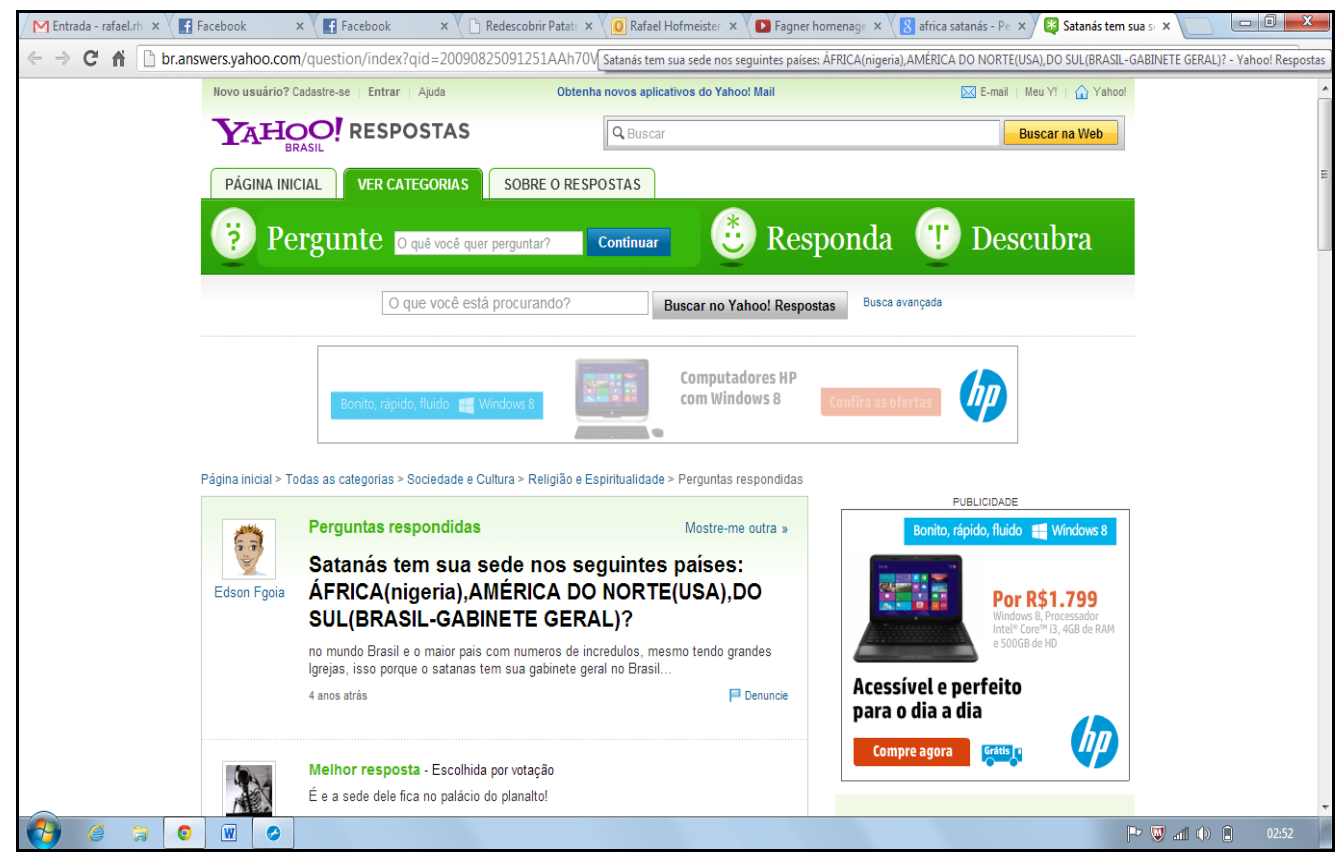

O segundo exemplo segue a mesma orientação ideológica. Há a pergunta se os demônios são provenientes da África (Imagem 4), o que está ligado a um preconceito com as religiosidades tradicionais africanas. 


\section{Imagem 4 - Os demônios vêm da África?}

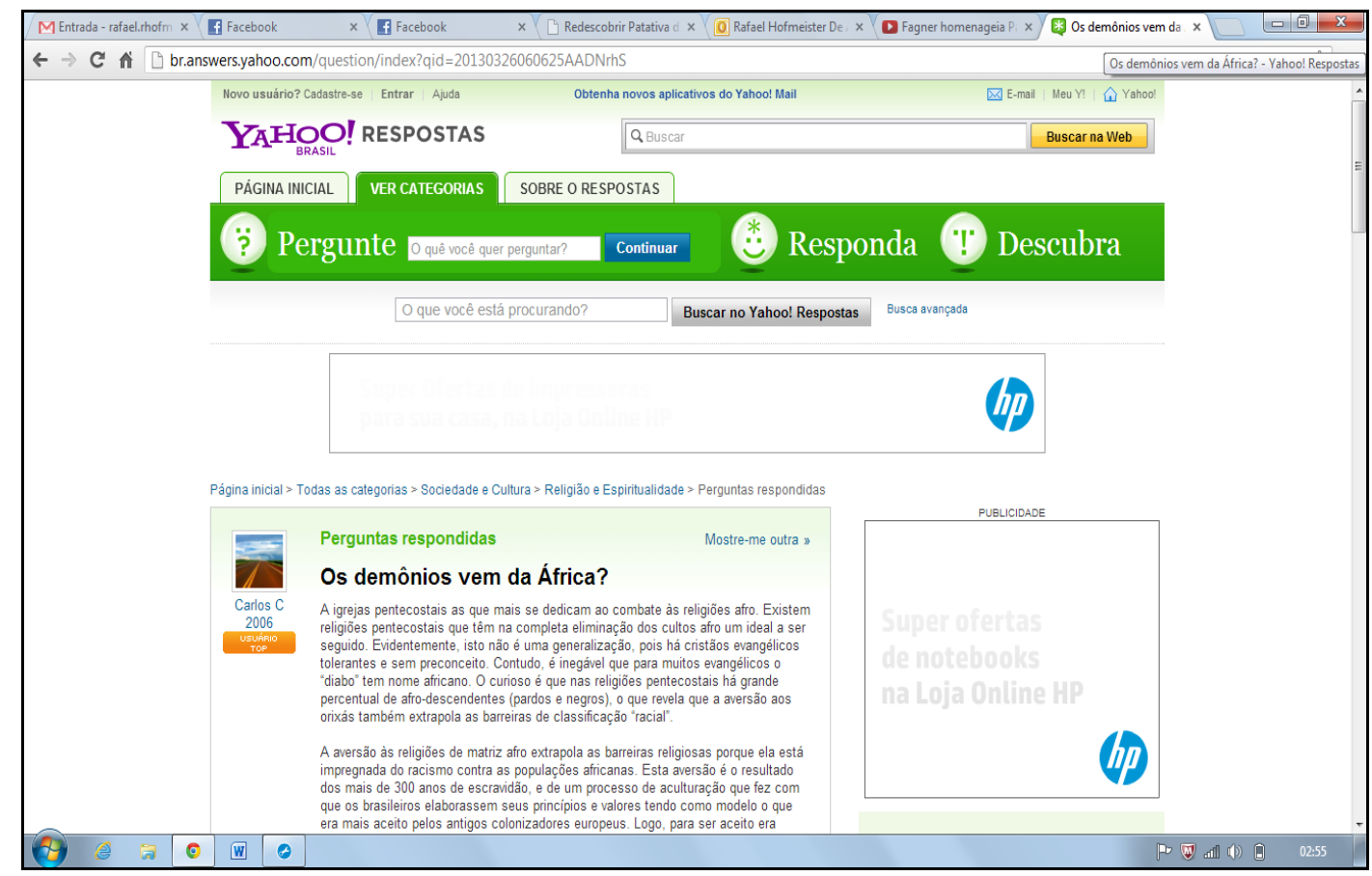

O preconceito com a religiosidade africana foi também encontrada em outro sítio (Uol blog). Há a declaração de que a religiosidade afro é atrasada e que é coisa "da Idade da Pedra" (Imagem 5).

\section{Imagem 5}

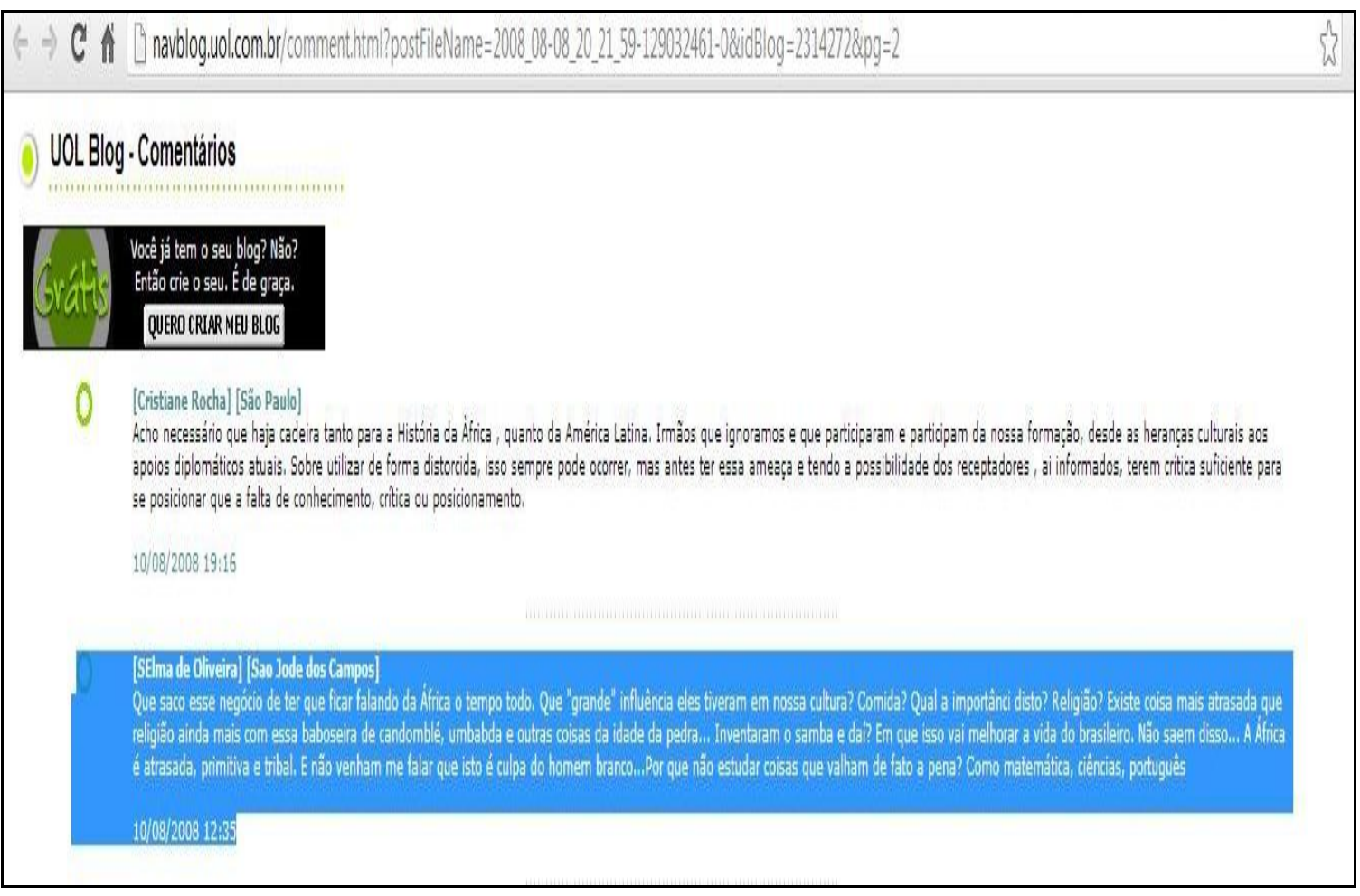


Perceptível está nas imagens 3,4 e 5, a representação do Outro como monstro. Tomados pelos padrões ocidentais e por uma representação neopentecostal, a África passa a ser a sede de Satanás e o local de onde provêm os demônios, engendrando o preconceito com as religiosidades tradicionais africanas.

\section{PARA LER ALGUNS SIGNOS DE ÁFRICA: O SÉTIMO JURAMENTO}

O sétimo juramento, publicado originalmente em 1999, é o terceiro romance de Paulina Chiziane, que não se considera uma romancista, mas uma contadora de histórias, a literatura para ela é um meio de registrar tudo aquilo que ouviu em sua constituição de sujeito africano. A obra narra a história de David, um ex-combatente pela Independência de Moçambique que é diretor de uma indústria estatal. O contexto da narrativa é o período de Guerra Civil pós-independência, portanto entre 1976 e $1992^{8}$, provavelmente próximo ao fim do conflito.

Tia Lúcia liga o rádio, é hora do noticiário. E os noticiários são quase todos
iguais, só falam de política, de políticos. Nesta terra política é agua, é pão, é
caixão. De repente, o locutor faz uma pausa longa, propositada. Quebra a
pausa com uma voz mais forte, para dar ênfase a uma notícia de extrema
importância e dia: "Última hora!" A guerra está para acabar. Os dois
beligerantes aceitaram sentar-se na mesa de conversações e discutem a
paz pela primeira vez. (CHIZIANE, 2000, p. 53).

David abandonou o passado como combatente socialista. Ele já não se importa mais com a construção de um Moçambique igualitário, mas somente com o seu enriquecimento material, inclusive por meio da corrupção, desviando os fundos da empresa estatal para contas em seu nome e de seus familiares no exterior.

Tirou alguns fundos para adquirir uma viatura nova e celebrar condignamente os quarenta anos de Vera, sua esposa. Tomou outros fundos para comprar acções de um grande empreendimento. Não se trata de fraude, nem de roubo. Foi uma transferência de fundos, uma espécie de empréstimo para criar capital, cuja reposição será feita na devida hora. Um diretor que se preza deve ter capital próprio, uma representação compatível com o cargo. (CHIZIANE, 2000, p. 14-15).

É a repetição da burocratização daquele Estado que se pretendia libertador, inclusive das divisões de classes, dissipando os privilégios daqueles que operassem, seja pela força das armas ou pela imposição discursiva, um domínio que 
sustentava a sua posição de superioridade, de distinção e de exploração ante ao proletariado e ao campesinato. Após destituir o poder político e econômico dos proprietários dos meios de produção e dispender esforços em prol do socialismo, a União das Repúblicas Socialistas Soviéticas (URSS), mirante da Frelimo (Frente de Libertação de Moçambique), abdica, sem que seja possível delimitar o momento, da construção de uma sociedade igualitária durante a vigência de um pós-capitalismo, segundo termo de Mészáros $(2007)^{9}$, e cai na consolidação, ainda que velada, de uma elite dirigente assentada em um capitalismo de Estado. Nesse sentido, a observação de Mandel (1989) é importante.

\begin{abstract}
A crise de sistema que reina na URSS aparece, portanto, como uma crise específica de uma sociedade específica, sociedade de transição entre o capitalismo e o socialismo, ainda incapaz de auto-regulação e de autoprodução espontânea, paralisada nesse estágio transitório de desenvolvimento pelos atrasos da revolução socialista mundial (o contorno capitalista), de uma parte, e pela tomada da sociedade por uma burocracia privilegiada e parasitária, de outra parte. (MANDEL, 1989, p. 61).
\end{abstract}

É salutar lembrar que Moçambique procura seguir o caminho soviético. Dessa forma, os desvios do caminho revolucionário ocorridos na URSS serão repetidos no país da África após a libertação do jugo colonial, reproduzindo arquétipos pol'ticoideológicos. Tais desvios são bem enfocados na trajetória de David no romance de Chiziane.

Inicialmente, o protagonista até pensa nos desvalidos de Moçambique independente. Nos homens que cantam à margem da vida o sofrimento passado no regime colonialista e a miserabilidade em que se encontram, agora, com a independência. Contudo, mesmo que lembre o passado de luta, ele conclui que todos os sistemas são tiranos - ele e os antigos revolucionários assumiram o lugar dos tiranos coloniais - e que, como ele investiu na independência e na revolução do e no país, deve gozar das benesses conquistadas.

Pensa com mais frieza. Neste mundo ninguém é bom para ninguém. Enganamo-nos uns aos outros. Tiranos brancos substituídos por tiranos negros, é a moral da história. Tirania é filha legítima do poder. Justiça e igualdade é negócio de Deus e não preocupação dos homens.

Imagens de um passado de glória correm na mente como fotografias. Treinos militares e guerra contra o colonialismo, marchas, combates. Sabotagem. Comícios. Discursos. Palavras de ordem. Euforia, sonhos, convicções. Vitória final sobre o colonialismo. Delírio colectivo no dia da celebração da independência. Recorda com saudade as sessões de estudo em grupo das políticas revolucionárias. Recorda a linguagem antiga. 
Camarada comandante, camarada pai, camarada esposa, camarada chefe. Muita amizade, solidariedade, camaradagem verdadeira. Naquele tempo tinha o coração do tamanho de um povo, mas hoje está tão pequeno que só abriga a si próprio. Agora, a palavra povo é um simples número, sem idade nem sexo. Sem sonhos nem desejos. Apenas estatísticas.

- No tempo da revolução investi. Agora estou na fase de egoísmo. Quero colher tudo que semeei. Este estatuto de director não foi dádiva, foi conquista. Lutei pela liberdade deste povo (CHIZIANE, 2000, p. 15).

Novamente, é possível um paralelo com a realidade vivida pela URRS, principalmente após o revisionismo de Khrushchov (1953-1964), aprofundado pelas políticas de Brejnov (1964-1982), Andropov (1982-1984), Chernenko (1984-1985) e, recebendo sua estruturação final no caminho de retomada do capitalismo, com Gorbachov (1985-1991) com a glasnost e a perestroika. Constrói-se um Estado burocrático de privilégios, em que magnatas do regime colhem os frutos, relegando grande parte da população a condições de pauperização.

Impera a corrupção e o desvio de capital público, construindo uma classe privilegiada que, pensando somente no próprio bem-estar, repete as configurações de classe inerentes ao capitalismo, podendo inferir que o pós-capitalismo da União Soviética constitui-se em um capitalismo de Estado.

\begin{abstract}
O interesse material dos burocratas, antes de tudo, os leva a aumentar seu acesso aos bens e serviços de consumo (seus rendimentos e vantagens não-monetários) e não otimizar o rendimento das empresas - sem falar da economia em conjunto - e certamente a não maximizar a taxa de acumulação. A oposição entre os interesses privados dos burocratas enquanto consumidores e o interesse (a racionalidade possível) do sistema econômico, tomado em conjunto, se traduz no trabalho corrente dos burocratas, que é fonte de desperdícios crescentes de recursos materiais e humanos: um influxo de informações falseadas que tornam impossível qualquer planejamento ótimo, estocagem ilegal de reservas; roubos maciços; mercados paralelos; mercados negros e trabalho negro; mercado cinza baseado na troca; corrupção generalizada; não transparência de toda vida econômica etc. (MANDEL, 1989, p. 63).
\end{abstract}

A narrativa de Chiziane apresenta, no contexto moçambicano do governo pretensamente revolucionário da Frelimo, desvios do rumo da construção de uma sociedade socialista tal quais os ocorridos no plano soviético. A personagem principal do romance retira fundos da fábrica estatal que dirige com o objetivo único do bem estar próprio, além de revelar uma clara concepção de que ele precisa se colocar como classe privilegiada, sustentando a existência de classes sociais que, teoricamente, a Frente de Libertação de Moçambique intentava acabar. 
A sua actuação é digna de censura. Faz o balanço. Os operários do açúcar não recebem há vinte e quatro meses. Os seus não recebem há apenas seis meses. Muito pouco tempo. Comparado com os outros diretores ele é um santo. Os motivos destes atrasos têm a sua razão de ser. Tirou alguns fundos para adquirir uma viatura nova e celebrar condignamente os quarenta anos de Vera, sua esposa. Tomou alguns outros fundos para comprar acções de um empreendimento. Não se trata de fraude, nem de roubo. Foi uma transferência de fundos, uma espécie de empréstimo para criar capital, cuja reposição será feita na devida hora. Um diretor que se preza deve ter capital próprio, uma representação compatível com o cargo. (CHIZIANE, 2000, p. 15).

Os desvios de fundos realizados por David, como se percebe na citação, geraram o atraso de seis meses de salários dos funcionários da fábrica. Diante disso e de uma onda de greves que assola o país, o diretor vê-se diante de uma greve eminente, percebendo-se como um explorador de igual monta ao do colonizador português em África.

Ninguém diz nada [acerca das reivindicações dos operários] e David mergulha na onda de medo. O lençol de lodo caminha rápido em direcção ao seu nome, ao seu prestígio. Na mente correm-lhe imagens do passado: reuniões clandestinas por ele dirigidas nas fábricas para sabotar o sistema. Activismo de primeira linha. Ódio à classe dominante do antigo sistema. Hoje ele é patrão e sente que vai ser escorraçado do poder tal qual fez aos colonos, pelas mesmas razões, pelas mesmas acções. Com os mesmos cantos e gritos. Com os mesmos slogans e palavras de ordem. Com a mesma fúria do povo oprimido. (CHIZIANE, 2000, p. 33, grifo nosso).

A greve será o elemento que conduzirá David ao encontro da África tradicional, a palavra escrita dos contratos milionários vai esmorecer ante o canto de dor da população. Ele percorrerá um caminho que o conduzirá para um embate entre os valores e crenças africanas e a ocidentalização que está presente em sua vida. Aliás, Ki-Zerbo aponta a ocidentalização como um dos fatores que proporcionou o fracasso do modelo socialista nos países africanos.

O segundo fator sociológico desfavorável esta representado pela forca das elites culturais africanas em suas relações com as classes econômicas enquanto tais. Em razão da fraqueza destas últimas, a única classe capaz de consumar a revolução socialista na África somente podia ser a elite. Infelizmente, esta elite era, em sua totalidade, formada por africanos fortemente ocidentalizados, os quais alimentavam o seu poder, não através da posse de riquezas, mas graças a incorporação de uma educação ocidental e pela aptidão no manejo do verbo. Assim, embora tornada revolucionária, ela não era capaz de fazer a revolução socialista, pois como pressentira Karl Marx, unicamente a classe menos favorecida das sociedades mais evoluídas - e não a classe mais favorecida constituída pela elite africana ocidentalizada - poderia consumá-la. Inclusive os africanos em viagem de estudos a União Soviética ou a China, forçosa e 
previamente, eram levados a ocidentalização pois, as obras de Marx, de Engels, de Lenin e de Mao não haviam sido traduzidas para as línguas africanas, como o kiswahili ou o yoruba. Consiste em um imperativo para um africano, trata-se de uma impossibilidade sociolinguística, ser um marxista por completo, sem, necessária e forçosamente, ser ocidentalizado. Pode-se, portanto e incontestavelmente, classificar a natureza da formação das elites africanas entre as características desfavoráveis do campo sociológico ao qual, no âmbito africano, foi confrontado o socialismo. (2010, p. 589-590)

A ocidentalização e assimilação da cultura ocidental estão presentes em David, atestando romanescamente a condição dos dirigentes socialistas africanos identificada por Ki-Zerbo. A personagem, ao procurar a ajuda de seu amigo Lourenço quando da deflagração na fábrica em que dirige, manifesta desprezo às tradições africanas. Em uma posição tipicamente ocidental, David se horroriza com a posição de entrega de Lourenço aos cultos africanos.

Lourenço está agora de pé, encostado à estante. David olha-o. Majestoso e elegante como sempre. Nem uma gordura a mais a deformar o corpo. Nem uma ruga na testa ou no canto do olho denunciando a idade. A boca sempre cheia de verdades, doçuras, certezas, hoje vomita o fel da vida. David lamenta: um católico, um intelectual transformado em cinzas, em nada. Uma hiena com vestes de cordeiro. A máscara cai revelando-se a vileza, o nojo. É como se um santo despisse o manto em plena missa, mostrando a face do vulgar e do terrível, escondido sobre as vestes. Dentro de cada homem há uma sombra oculta, um ser desconhecido. Ninguém consegue compreender os segredos da alma. (CHIZIANE, 2000, p. 44-45).

Ademais, a narrativa de Chiziane aponta para uma ocidentalização da revolução moçambicana que produz um silenciamento das tradições africanas. $\mathrm{Na}$ busca de um mundo socialista, os combatentes e militantes da Frelimo põem-se a destruir templos e perseguem aqueles que praticam a religiosidade de matiz autóctone.

David coloca a memória nos tempos da revolução. Como militante do mundo novo, ordenara incêndios de nunca acabar, queimando ndombas, mutundos, magonas e lugares de culto, para libertar a terra dos adoradores das trevas. Mergulha num remorso sem fim. Pensa em si. Que seria da minha vida agora, se os adivinhos e curandeiros tivessem desaparecido da superfície da terra? Sente necessidade de confessar crimes antigos. Ganha coragem. Desabafa. O adivinho tranquiliza-o. (CHIZIANE, 2000, p. 80-81).

As palavras do adivinho retratam uma perseguição sistemática à religiosidade africana. Elas revelam que a perseguição se deu tanto no âmbito do colonialismo quanto no da tentativa de construção de um Moçambique socialista. Todavia, há a 
constatação de que mesmo os perseguidores efetuam um movimento de valorização da cultura religiosa moçambicana; movimento, aliás, que David executará ao longo da trama narrativa.

A perseguição não começa hoje. Fomos desprezados, humilhados, combatidos, mas resistimos. Demos suporte aos regimes políticos que nos perseguiam. Demos força e coragem aos guerreiros antigos e modernos. Elevámos a moral dos combatentes durante as guerras contra os regimes coloniais. Hoje, damos suporte espiritual aos políticos que ontem nos perseguiam, aos padres, ministros, banqueiros e até académicos de alto nível. Reabilitamos psicologicamente os criminosos de guerra. Consolamos o povo no momento de grandes crises. Tivemos sempre um papel social de grande utilidade. Enquanto 0 mundo existir, existiremos, porque 0 curandeirismo é obra de Deus e não invenção humana. (CHIZIANE, 2000, p. 81).

Da voz do adivinho, surgem verdades que se materializam historicamente. Ele abandonara a carreira de advogado para se tornar um curandeiro, assumindo a posição de dono da palavra, para utilizar a expressão de Colombres (1997), e portador de um "saber" que "vem de um sistema particular baseado na tradição africana" (CHIZIANE, 2000, p. 81). O próprio David reconhece os adivinhos como aqueles que são portadores da palavra capazes de dizerem, utilizando-se da performance (COLOMBRES, 1997; ZUMTHOR, 2013), "palavras invocativas em gestos e cantigas. Palavras santas" (CHIZIANE, 2000, p. 83). Em dois momentos ao menos, David reflete sobre essa capacidade dos adivinhos. No primeiro, quando são jogadas as conchas para prever o seu futuro.

Os adivinhos usam linguagem enigmática para tornarem inacessível o seu mundo. Os médicos fazem o mesmo. Entulham os ouvidos dos doentes com palavrões latinos que lhes levaram anos de aprendizagem, apenas para exibirem o seu saber e seu charme. David busca consolo em si próprio. As conchas não falaram de morte, mas de vida. Não falaram de desespero, mas de uma esperança coberta de mistérios. (CHIZIANE, 2000, p. 88).

O segundo acontece durante a cerimônia de lobolo, quando David conclui que os "padres, os filósofos, curandeiros, psicólogos, são membros da mesma confraria. Por vezes escondem a sua incapacidade de resolver problemas, dizendo coisas que ninguém entende. Refugiam-se na fortaleza da língua para se tornarem inacessíveis" (CHIZIANE, 2000, p. 99).

O que David parece não compreender é que toda essa suposta inacessibilidade provém da própria condição dos donos da palavra. Seguindo a 
acepção de Colombres (1997), a palavra proferida como sagrada na concepção da tradição religiosa só pode ser compreendida pelos iniciados e a condição de David é daquele que abandonou a sua raiz, o que torna as palavras do adivinho inacessíveis. O processo de ocidentalização foi tão forte em David que ele se pôs em luta com a palavra oriunda da tradição africana, inclusive negando o nome advindo da tradição ao seu filho.

$\mathrm{Na}$ primeira gravidez, os mais velhos olharam para a barriga e prognosticaram: será homem. Será o sal da vida, a luz nas trevas. Pagará as promessas e as dívidas antigas. Vencerá as manhas de Dumezulu, a serpente do céu, quando castiga o universo inteiro com o ribombar malicioso. Chamar-se-á Mungoni, o guerreiro! David disse logo que perante o desejo dos antepassados. (CHIZIANE, 2000, p. 63).

O próprio David negou a si o nome advindo da tradição. Ele desconsiderou que "el nombre no es la forma en que la persona es designada: el nombre es la persona, posto que designa su alma, y los atributos de ésta son sus atributos personales, que conservará hasta la muerte" (COLOMBRES, 1997, p. 38) ou mesmo após a morte, encarnando-se em outro ser como aparece dito nas palavras do adivinho.

- Esse nome não te identifica perante os deuses.

- Sou David e nada mais.

- Faz um esforço, vá, não se pode invocar os espíritos com nome alheio.

Vamos, diz-me o nome sem o qual essa adivinhação não será possível.

- Os velhos me chamavam de Magagule.

- Chamavam-te e ainda assim te chamam. Diz-me o nome do teu pai e o teu apelido.

- Magagule Machaza Cossa. Um nome longo e feio, não achas?

- Nome é herança sagrada. É matéria, espírito, vida e morte. Através dele os mortos se encarnam e os vivos transmigram. Nome é anterioridade e posteridade. Em resumo, é o universo inteiro em poucas palavras. Não sabes, mas compreendo-te, a história foi demasiado cruel com os nossos povos. (CHIZIANE, 2000, p. 82-83).

Todavia, David sabe que deve voltar a habitar o seu nome verdadeiro, Magagule. Esse habitar inclui o retorno às raízes e a retomada da religiosidade tradicional africana. Mesmo que a princípio, as encare com certo ceticismo, a situação de desespero em que se vê exige que ele se reencontre com a tradição, daí seu apelo aos objetos mágicos antes da reunião com os outros diretores da fábrica e o pronunciamento diante aos operários.

Pára à entrada da sala de reuniões e recorda as instruções da feiticeira. Abre a pesada mala e contempla os talismãs e os bruxedos. E o cepticismo 
vem. Aquelas bugigangas foram usados pelos homens das cavernas e por todos antepassados da era primitiva. Agora são usados por ele. Ri-se de si próprio enquanto cumpre a risca com a receita mágica, uma pessoa desesperada é obediente, porque não tem escolha numa decisão sobre a própria vida. (CHIZIANE, 2000, p. 111).

$\mathrm{O}$ ato de aceitar os mistérios permite que David seja tocado pelo dom da palavra e consiga, na "batalha das palavras" (CHIZIANE, 2000, p. 111), vencer os outros diretores. Ainda mais, dotado de poder, percebe que necessita apelar à performance e, nessa, o Outro que ouve é um coautor do discurso que é proferido (ZUMTHOR, 2011; COLOMBRES, 1997) e, assim, é preciso conquistar os operários, fazendo com que eles habitem o discurso pronunciado.

David avalia o ambiente. Os rostos de miséria que a sua administração criou exibem-se aos seus olhos. Alguns daqueles operários foram companheiros de luta nas greves de ontem. Esses homens foram, no passado, verdadeiros generais do proletariado, lutadores corajosos como já não se encontram nos dias que correm. Gente de grande liderança, verdadeiros pensadores. Devem ser eles os principais mentores da greve. David pensa em desembaraçar-se deles. Encontrará jeito para isso. (CHIZIANE, 2000, p. 111).

Cônscio que o poder da palavra está intimamente ligado a uma execução performática adequada, David prepara a sua performance para encantar os ouvintes. Ele sabe que a palavra pode salvá-lo no grande palco da vida; que o encanto da palavra performática pode esmorecer os ânimos dos operários e encerrar com a greve.

David faz recurso à magia do palco. Os políticos são actores. Os lideres de todas as coisas são actores. A vida é um enorme palco e cada homem é um actor, um espectador. Um bom discurso de palco é a solução de todas as coisas porque os operários têm fome de pão, mas também de palavras doces. (CHIZIANE, 2000, p. 115).

O regresso à tradição faz com que David conquiste seus intentos, todavia, ao alcançá-los, o protagonista abandona a feitiçaria. Na batalha entre a ocidentalização e a volta à tradição, nesse primeiro momento, vence aquela.

David decide voltar à vida antiga. É bonito respirar com liberdade a brisa do mar. Varrer o lixo do peito e ganhar a limpeza interior dos oceanos. Lavar a alma com água pura, cristalina. Libertar a força e enfrentar a vida com punhos de homem.

Olha para os objetos com nojo estampado no rosto. Limpa o chão e faz desaparecer todos os vestígios de culto, disposto a abandonar aquele 
mundo de loucura. Coloca todos os objetos dentro de um saco de plástico para atirar nas lixeiras da estrada. (CHIZIANE, 2000, p. 128).

A resposta da tradição é uma nova queda de David. Dessa vez, é mais abrupta, pois a personagem está envolvida em uma teia de corrupção pronta a ser desvelada e que pode leva-lo ao cárcere. A palavra contida nos contratos e no sem número de papéis da máquina burocrática denotam a exotopicidade do arquétipo colonial. Isso faz com que busque a proteção em Makhulu Mamba. O encontro com Makhulu Mamba faz com que David reflita sobre o processo de assimilação dos valores ocidentais e como daí se produz um hibridismo cultural. O momento também faz com que David revisite a tradição africana que abandonou, a reminiscência faz com que ele se abra para habitar novamente um universo que the foi silenciado: o universo da África não ocidentalizada.

\begin{abstract}
A memória recua. Recorda lendas, fábulas, história de feitiçaria. Makhulu Mamba é nome de um personagem das lendas de terror do universo mítico dos Tsongas, que remetem as crianças às noites de delírio e pesadelos. Makhulu Mamba é uma personagem lendária ou real? A intriga cresce. Será Lourenço o filho de um feiticeiro? Deve ser. Ele é um bom cristão mas navega no mundo oculto como um peixe. Muitos dos assíduos frequentadores da igreja usam a Bíblia para camuflar o feitiço. Cristãos de dia, feiticeiros de noite. (CHIZIANE, 2000, p. 139).
\end{abstract}

O protagonista está prestes a realizar o seu sétimo juramento. Depois de ter jurado no batismo, à bandeira, no matrimônio, a servir à revolução, a servir à nação no dia de sua graduação, a ser competente e ter zelo com a empresa na posse como diretor, ele vai fazer um juramento que talvez não tenha volta: o juramento a servir Makhulu Mamba. Isso fará com que ele acabe aderindo à feitiçaria negra.

Fiz o juramento do baptismo, juramento da bandeira, matrimónio, jurei servir a revolução e lutar pela independência, jurei servir a nação no dia da minha graduação, jurei competência e zelo na tomada de posse como diretor na empresa.

- Fizeste já seis grandes juramentos. Cumpriste com todos?

- Dei umas dentadas uma vez e outra.

- Este juramento será então o sétimo em tua vida.

- Sim, o sétimo, se jurar.

- Vai correr tudo bem. Sete é um número de sorte. (CHIZIANE, 2000, p. 152).

Esse caminho que David toma trará muito sofrimento a si e a sua família. Por isso, Clemente, seu filho, habitando o nome que Ihe fora negado, Mungoni, prevê os males que advirão. 
- Sinto o piar dos mochos. É a morte a rondar a casa. Mãe, sinto que a morte está próxima, o pai foi à busca da morte e nós vamos morrer, mãe! $[\ldots]$

- Agora mesmo acabei de ver uma imagem pavorosa. No princípio, projectou-se como uma simples fotografia tipo passe e foi crescendo, crescendo. E tornou-se uma imagem viva, mas muda. Era uma mulher. E viIhe os cabelos longos, pintados de barro, e o corpo todo de branco de cinza e cal. Vestia uma longa túnica de peles. Segurava na mão direita um longo cetro de ouro e oferecia-me um sorriso de morte. Era a monstra da floresta, a guardiã dos túmulos, a inominável feiticeira dos séculos, daquelas histórias que a avó Inês conta. Fechei os olhos, horrorizado, mas quando voltei a abri-los a feiticeira era Suzy. Quando se viu descoberta soltou a matilha de lobos que me perseguiam e eu corria como um louco. (CHIZIANE, 2000, p. 153-154).

David realmente cometerá atos abomináveis como a prática do incesto e a transformação de sua filha Suzana em uma serva sua e, consequentemente, de Makhulu Mamba. Para evitar a morte que previu e fazer com que os males que pairam sobre a sua família, Clemente assume-se como aquele que será "o sal da vida, a luz nas trevas" (CHIZIANE, 2000, p. 61), resolvendo se tonar curandeiro e lutar contra a feitiçaria negra.

\footnotetext{
Clemente dialogava com a sua alma, que o incita à acção. Só pode agir quem está armado. Aproxima-se da mãe e dá-lhe um abraço e comunicalhe a sua decisão.

- Mãe, eu quero servir a Deus como curandeiro.

Vera, apanhada de surpresa, fica boquiaberta.

- O quê?

- Quero aprender todos os segredos da magia, do antifeitiço. Faço-o por mim, por ti, por toda a família.

- Enlouqueceste?

- A magia negra impera. Por todo o lado há crimes rituais, incesto, mutilações, mortes, desespero. Gente de todos os estratos sociais busca alicerces na magia negra, para subir na vida sacrificando os parentes, os amigos e até desconhecidos. (CHIZIANE, 2000, p. 243).
}

O jovem seguirá uma trajetória de aprendizagem nas escolas de curandeirismo no interior de Moçambique, recuperando uma tradição oral perdida no sistema colonial. Ele acabará por se tornar um poderoso curandeiro capaz de vencer o pai, libertando o protagonista do sétimo juramento por meio da derrota de Makhulu Mamba no embate final, no derradeiro momento do romance.

David olha de novo para a janela e fica petrificado. Makhulu Mamba agora empunha a flecha em posição de morte, enquanto tambores rufam cada vez mais alto, saudando antecipadamente a recepção do novo membro no exército das sombras. Clemente larga o pai que cai sobre o solo como um fado. Mete a mão no bolso. No exacto momento em que a flecha está a uns 
centímetros do alvo, esta quebra-se maravilhosamente, contra-atacada por uma pedra, a mesma pedra de Wassapa que os salvou da morte na noite de Dumezulu. $O$ exército de Makhulu Mamba dispersa porque descobre que o alvo é invulnerável.

Clemente ajoelha-se e ampara o pai que baba. Leva-o nos seus braços, para a cama. Sob o olhar sereno da mãe, Clemente faz os possíveis para reanimar aquele corpo atormentado.

David agarra-se desesperadamente ao filho e solta o último suspiro. (CHIZIANE, 2000, p. 264).

Embora a libertação ocorra com a morte do protagonista, há o reestabelecimento da ordem. Esse reestabelecimento não se dá pelas vias ocidentais, através da religião cristã e sua prática já tematizada inúmeras vezes na ficção do exorcismo, mas através da tradição africana, rompendo com silenciamentos impostos culturalmente, recuperando a tradição perpetuada na oralidade e, ainda, negando a palavra escrita em contratos corrompedores.

\section{ALGUMAS ÚLTIMAS PALAVRAS}

A crueldade da história com os povos de África revela-se nos silenciamentos impostos pela ocidentalização proveniente dos colonialismos, não só o real, empiricamente sentido na pele, mas também o simbólico, o ideológico, impondo, no curso da busca de igualdade entre os moçambicanos, como já visto, de um matiz socialista que desconsidera a tradição africana. Tais silenciamentos são rompidos no romance de Chiziane. Por esse motivo, logo no início da narrativa, o enunciador procura reabilitar a tradição oral moçambicana através das histórias contadas pela avó Inês a Clemente.

A avó Inês vai ao quarto de Clemente. Desperta-o. Toma-o nos braços com
uma nova força extraordinária, como quem segura a mais preciosa das
relíquias. Procura na mente histórias de encantar, mas a memória corre
para o passado de mistérios e de verdades ocultas. Diz ditados e fábulas.
Embala-o. Diz que a vida é como água, nunca esquece o seu caminho. A
água vai para o céu mas volta à superfície. Vai para o subterrâneo mas
volta à superfície. A vida é um eterno ir e voltar. O corpo é apenas uma
carcaça onde a alma constrói a sua morada. Depois conta a mais bela
histórias de encarnação. (CHIZIANE, 2000, p. 26).

Não só a oralidade aparece de forma marcante no princípio da narrativa como também a religiosidade tradicional. $O$ universo mítico africano constitui-se presente na ligação entre as trovoadas e Dumezulu. 
O dia de trovoada é dia de terror. Dia de Dumezulu, a serpente do céu. Dia do galo negro vencedor de todos os combates. Dia em que Xango, o terrível deus da guerra e da morte, atira as flechas de Ogun para demonstrar os seus poderes infinitos de castigar todos os que provocam a sua ira. No dia de trovoada os curandeiros abrem todas as magonas fazem uma prece à trovoada, gritando: "Dumezulu, estas são as minhas magonas. Veja com seus olhos, não tenho nenhuma alma prisioneira. As minhas ações são benéficas, nunca comi ninguém. Dumezulu não me castigue, Dumezulu poupa-me, não me castigue, sou seu servo." (CHIZIANE, 2000, p. 24).

Afora isso, toda a trajetória de David, que se procurou reconstituir no artigo, oscila entre os signos da ocidentalização e da tradição. Esse embate é o campo de luta simbólico que se descortina na narrativa de Chiziane. Em tal campo de batalha, há a compreensão de que a ciência ocidental é incapaz de lidar com certos fenômenos, tal qual revela as palavras de Vera, esposa de David, acerca dos distúrbios que atingem Clemente: "A solução de tudo isso é um bom psiquiatra. Infelizmente, para este caso, o psiquiatra tem feito as mesmas perguntas e dá sempre as mesmas respostas, os mesmos remédios. No lugar de melhorar, as coisas pioram" (CHIZIANE, 2000, p. 154). Disso resulta a valorização dos saberes da tradição moçambicana, tantas vezes silenciados no decorrer da história, como bem constata Maria Paula Meneses (2004, p. 724).

O mosaico cultural que é Moçambique é um indicativo da riqueza de saberes que o país possui. Todavia, hoje em dia, quando falamos em saberes, a perspectiva dominante atribui à ciência um caráter central, sendo o conhecimento local, tradicional, descrito como alternativo ou periférico. Tal situação é reflexo do processo histórico que o país atravessou durante os últimos anos.

O romance de Chiziane, desse modo, promove um rompimento com os silenciamentos históricos impostos a Moçambique e à Africa, procurando reestabelecer a tradição e seus saberes. Tradição recuperada e materializada ficcionalmente pela autora que ao engendrar um narrador para seu romance, gesta, também, um mecanismo de recuperação da memória oralizada que a compõe.

\section{NOTAS}

\footnotetext{
${ }^{1}$ Atua nas disciplinas de Antropologia e Filosofia no Núcleo de Educação a Distância da Universidade Feevale. É mestre em Processos e Manifestações Culturais pela mesma Universidade e doutorando em Literaturas Portuguesa e Luso-Africanas pela Universidade Federal do Rio Grande do Sul. Desenvolve, atualmente, tese de doutoramento sobre uma tradição lusófona do improviso, atualizada nas performances e nas obras de Patativa do Assaré e de outros poetas e repentistas do sertão brasileiro.
} 
${ }^{2}$ É doutor em Literatura Brasileira, Portuguesa e Luso-africana pela UFRGS. Professor do Curso de Letras e do Mestrado em Processos e Manifestações Culturais da Universidade Feevale. Tutor PETinterdisciplinar (MEC/FNDE).

${ }^{3}$ É doutora em Literatura Brasileira pela Universidade Federal do Rio Grande do Sul. Atualmente é professor adjunto da Universidade Federal do Rio Grande do Sul. Tem experiência em ensino e pesquisa em Literatura Brasileira e Literaturas Portuguesa e Luso-Africanas, com ênfase nos seguintes temas: narrativa oral, história, identidade, modernidade, culturas populares, performance e ensino. É coordenadora do GT de Literatura Oral e Popular da ANPOLL (Biênio 2012-2014).

${ }^{4} \mathrm{O}$ conceito de "burguês" e suas variantes, neste trabalho, segue as acepções usadas por Césaire (1953) e Albert Memmi (1977).

${ }^{5}$ Disponível em: <http://www.youtube.com/watch?v=AvEwkFhB_Qo>. Acesso em: 09 jul. 2013.

${ }^{6}$ Disponível em: <http://www.youtube.com/watch?v=9U-FA8Gthr4>. Acesso em: 09 jul. 2013.

7 Disponível em: <http://open-up-your-mind-bookstore.blogspot.com.br/2013/04/as-aventuras-detintim-na-africaherge.html>. Acesso em: 09 jul. 2013.

${ }^{8}$ De acordo com dados oficiais disponíveis em: <http://www.portaldogoverno.gov.mz/Mozambique/ resHistorico>. Acesso em: 09 jul. 2013.

${ }^{9} \mathrm{O}$ pensador marxista afirma que o que a URSS viveu, assim como países como China, Vietnã e Cuba, na atualidade, é uma fase de pós-capitalismo e não propriamente de um socialismo, fugindo do incômodo conceito de socialismo real.

\section{REFERÊNCIAS}

BURKE, P. Testemunha ocular: história e imagem. Bauru, SP: EDUSC, 2004.

CÉSAIRE, Aimé. Discurso sobre o colonialismo. Lisboa: Livraria Sá da Costa, 1953.

CHIZIANE, P. O sétimo juramento. 3. ed. Cacém: Caminho, 2000.

COLOMBRES, A. Celebración del linguaje: hacia una teoría intercultural de la literatura. Buenos Aires: Ediciones del Sol, 1997.

KI-ZERBO, J. et al. Construção da nação e evolução dos valores políticos. In: MAZRUI, A. A.; WONDJI, C. História geral da África, VIII: África desde 1935. Brasília: UNESCO, 2010. p. 579-580.

MANDEL, E. Além da perestroika: a era Gobachov e o despertar do povo soviético. São Paulo: Busca Vida, 1989.

MEMMI, Albert. Retrato do colonizado precedido pelo retrato do colonizador. Rio de Janeiro: Paz e Terra, 1977.

MENESES, M. P. Agentes do conhecimento? A consultoria e a produção do conhecimento em Moçambique. In: SANTOS, B. S. Conhecimento prudente para uma vida decente. São Paulo: Cortez, 2004. p. 721-755. 
MÉSZÁROS, I. O desafio e o fardo do tempo histórico. São Paulo: Boitempo, 2007.

SHOHAT, E.; STAM, R. Crítica da imagem eurocêntrica: multiculturalismo e representação. São Paulo: Cosac Naify, 2006.

ZHUMTHOR, P. Introdução à poesia oral. Belo Horizonte: UFMG, 2010. 